\title{
Health and Vulnerable Men Sweden: From Traditional Farming to Industrialisation
}

\author{
Jan Sundin and Sam Willner
}

I $\mathrm{n}$ every society, there are different kinds of resources for good health. For instance, social capital matters - formed in networks by members of the local community and supported by concerned public and private institutions. Finding ways to understand these processes, which are the most vulnerable groups and why it happens is a major theme for the following narrative.

An analysis of the relationship between health and social transitions during the late eighteenth and nineteenth century in Sweden must, due to the availability of sources, rely mostly on mortality figures and history has to be divided into three, partly artificial periods, making the social change visible:

The classical agrarian society, until c. 1800

The transition of the agrarian society before industrialisation, c. 1800-1860/70

Industrialisation and the classical industrial society, c. 1860/70 -

Each of these periods was characterised by specific mortality patterns, in certain ways linked to socio-economic factors. In addition, however, due consideration must be given to public health interventions by local and national government. In this story, the emphasis is put on the second period. It will be argued that the rapid transitions during the first half of the nineteenth century, for some groups and especially for adult men, created what is today described as social stress. It was reflected in a male mortality hump strikingly similar to the one that has been observed to a varying degree in the former Soviet empire after 1989. Such comparisons, however delicate because of all the differences, might help to identify and understand some of the more common connections between health and social transitions, but also underline the influence of specific contexts. 


\section{The Classical Agrarian Society}

Until the nineteenth century, Sweden can be defined as a classical, l'ancien regime agrarian society. A vast majority of the population earned its living from farming and, especially in the forest areas in the north, from hunting, fishing and forestry. The minority, about 10 percent, lived either in the little towns in the households of craftsmen and merchants, or in relatively small iron foundries. War, infectious diseases and years of crop failures kept population growth at a modest rate. The age of marriage fluctuated according to the possibilities to become a farmer, craftsman or foundry worker and form a new family. Hence, with few illegitimate births, the size of a new generation was limited by its possibilities to marry and by its high mortality, especially among children but also among adults in the Middle Ages. Upward or downward social mobility between generations was an exception. ${ }^{1}$

Luther's Haustafel stated that each person had a given place on earth, which seemed to be in line with the existing social order. ${ }^{2}$ The Bible, interpreted by the orthodox protestant priests, and Luther's Catechism, read and memorised by everybody, were the official guidelines for a good Christian life. These rules were internalised by a system of home education where the parents were obliged to teach their children to read and to memorise the central religious texts. Annual catechetical examinations of all persons above the age of seven took place ensuring that these duties were fulfilled and that nothing was forgotten later in life. In the countryside, parish meetings and village boards handled both spiritual and secular affairs. The priest, who should make sure that the decisions were in accordance with religious norms and secular laws, chaired these meetings. Special attention was paid to church discipline, not only concerning purely religious shortcomings but also juvenile delinquency, family disputes, drunkenness and other disorderly behaviour, which was not serious enough to be brought to the civil courts. Many parishes appointed village guards who should report about all kinds of "unrest" among their neighbours. ${ }^{3}$ In this 'tight' local society, being obedient to the authorities and co-

1 L. Edgren, Lärling, gesäll, mästare. Hantverk och hantverkare i Malmö 1750-1857 (Lund, Dialogos, 1987); B. Harnesk, Legofolk: drängar, pigor och bönder i 1700- och 1800-talens Sverige. Umeå Studies in the Humanities 96 (Almqvist \& Wiksell International, 1990); A. Hörsell, Borgare, smeder och änkor. Ekonomi och befolkning i Eskilstuna gamla stad och Fristad 1750-1850. Studia Historica Upsaliensia 131 (Stockholm, 1983); Ch. Lundh, The World of Hajnal Revisited. Marriage Patterns in Sweden 1650-1990. Lund Papers in Economic History 60 (Lund, Department of Economic History, University of Lund, 1997); C. Winberg, Folkökning och proletarisering. Kring den sociala strukturomvandlingen på Sveriges landsbygd under den agrara revolutionen. Meddelanden från Historiska Institutionen i Göteborg 10 (Göteborg, 1977). 1970).

2 H. Pleijel, Hustavlans värld: kyrkligt folkliv i äldre tiders Sverige (Stockholm, Verbum,

3 E. Johansson, The History of Literacy in Sweden in comparison with some other countries (Umeå University and School of Education, Umeå, 1977); J. Sundin, 'Control, punishment and 
operating with one's neighbours was the sensible way to become accepted and to avoid many problems. A majority of the population belonged to these 'insiders' while those who broke the rules and challenged the order became 'outsiders'. As an insider one could also hope that relatives, neighbours, guilds and other more or less informal institutions and networks intervened and tried to assist in difficult situations. Outsiders were looked upon with less compassion.

Being an insider was even more important since survival was always at risk. A harvest failure meant that the next year had to be endured at or sometimes even below the level of subsistence. Such years were often accompanied by an increase of migration and the spread of epidemics. During wars, generations of young men were drafted and many of them never came back to their home parishes. War consumed money and extra taxes put burdens on the whole population. War was also a source of epidemics, affecting both soldiers and civilians. Smallpox, measles, whooping cough, diarrhoea and other infections killed 20-35 percent of the infants and large numbers of those who survived their first year of life. In addition, dysentery, typhoid fever and other epidemics hit in all ages, making life more difficult for the survivors in the family. Death had to be accepted as the result of God's mysterious will. Seen from the point of view of the individuals, there was little they could do to prevent these events. Living a Christian life and relying on the 'Gemeinshaft' and social capital invested in kin and neighbours could, however, be a source of support for the sick and in other ways unfortunate. And, in the end, the Bible promised eternal life for the faithful. While unpredictable in one sense, society was governed by simple rules and traditions. ${ }^{4}$

reconciliation. A case study of parish justice in Sweden before 1850' in Anders Brändström and Jan Sundin, eds., Tradition and Transition. Studies in microdemography and social change. Report no. 2 from the Demographic Database, (University of Umeå, 1981); J. Sundin, 'Världslig pragmatism och religiöst nit. Om sexualitetens gränser i Sverige 1600-1850', Norsk Historisk Tidskrift, 2 (1991); J. Sundin, För Gud, Staten och Folket. Brott och rättskipning i Sverige 16001840. Rättshistoriskt bibliotek XLVII (Lund, 1992); J. Sundin, 'For God, State and People. Crime and Local Justice in Pre-Industrial Sweden', in Eric Johnson and Eric Monkkonen, eds., The Civilization of Crime. Violence in Town and Country since the Middle Ages, (University of Illinois Press, 1996 b).

4 J. Sundin, 'Vägen mot ett längre liv. Socialhistoriska aspekter på prevention under 1800-talet' in Ola Arvidsson and Gösta Carlsson, eds., Kampen för folkhälsan. Prevention i historia och nutid, (Natur och Kultur i samarbete med FRN, Stockholm, 1994); J. Sundin, 'Culture, Class and Infant Mortality During the Swedish Mortality Transition, c. 1750-1850', Social Science History, 19:1 (Spring 1995); J. Sundin, 'Child Mortality and Causes of Death in a Swedish City, 1750-1860’, Historical Methods, 29:3 (1996 a), 93-106. 


\section{Life in Early Nineteenth-Century Sweden}

Usually, social historians study aggregated numbers of people, trying to find regularities or patterns that can tell something about society. This is a necessary task in order to get information about the structural factors and their interplay. Individual life histories are - if at all presented - usually illustrations, giving the readers a feeling that the story is really about human beings of flesh and blood. Individual life histories can also serve as a tool for empathy with the people under study. They can, however, also create hermeneutic understanding beyond mere figures, that only the unique - and yet often in many respects representative - life can represent. Before entering the "macro-history" of early nineteenth-century Sweden, the rich Swedish population registers will introduce us to the concrete lives of the poor in pre-industrial Linköping.

Dramatically high rates of infant mortality could be found in some families during the decades before 1800, for instance among the offspring of the postman Johan Peter Dahlström and his wife Sara Christina Påhlman. This couple was born outside Linköping. Johan Peter arrived in 1789 from Denmark, 27 years old, and Sara Christina was 35 years old, when she came from the city of Vadstena in 1790. They married in 1792 and had nine children (including three twin couples) between 1792 and 1799, all dying before their first birthday. Twins had a high fatality rate, usually because of their weakness at birth. The common cause of death for these nine children was, according to the register of deaths and burials, "slag" stroke, which only tells us that death had come suddenly. This diagnosis is, however, often related to diarrhoea and other infections caused by the introduction of contaminated food at an early age. Bad hygiene can also have been one of the factors in the Dahlström family, indicated by the diagnosis "thrush" for one of the deceased children. Thrush is a non-fatal infection in the mouth and throat, caused by bad hygiene.

Finally, in 1800, a daughter, Sophia Christina, was born who survived childhood, like her brother who was born in 1802. The birth register calls their mother "madam", which tells us that her husband belonged to the lower middle class. Sophia Christina's chances looked relatively good compared with the social situation of many children born in the pre-industrial urban proletariat. Her mental capacities were also good, according to the marks in 'reading' and 'comprehension' given by the priest in the church examination records. Her brother was even called "scholaris", which tells us that his parents had sent him to the elementary school. He left Linköping for good when he was only 15 years old.

The daughters of the middle classes usually married when they were about 24-26 years old, but Sophia Christina appeared in the register already when she was 19. The reason for this young matrimony is recorded in the birth register, which tells us that the new couple had a son, Claes Johan, one month after the wedding. 
Illegitimate births were a shame in Sophia Christina's social milieu, and we have strong reasons to believe that she "was forced to marry", according to the current terminology. This would also explain why she or her parents had chosen a husband of dubious social and moral character. Olof Claes Fredriksson was a drafted military musician, who had been tried for theft, but the case "rested" due to lack of proof. For some years, however, life seemed to be relatively calm and free from dramatic incidents and another son, Gustaf Herman, was born in 1822.

One event, which probably turned Sophia Christina's life course towards its tragic end, occurred in 1828, when her husband moved and became a trumpeter at the Crown Prince's regiment in Helsingborg, 400 kilometres south of Linköping. Her father had already died of cold and she was left alone with an ageing mother and two young sons. In 1832, she had an illegitimate son, either as the result of a casual relation or because she tried to make a living from prostitution. The child died a year later of "slag" and other misfortunes followed. Sophia Christina and her mother were convicted of illegal sale of alcohol several times, a common way of making a living for poor women. Her sons were convicted of attempted burglary when they were 15 and 12 years old. The older son, Claes Johan, started a career as "professional thief" a year later, when he was sent to the prison in Stockholm and did not return to Linköping until after his mother's death, then and ex-prisoner and ex-inmate at an institution for compulsory work.

Gustaf Herman was luckier and became an apprentice at a bakery when he was 15 years old, before his father returned to his wife in 1838. Sophia Christina's husband had been dismissed from his regiment (because of his age or misconduct). It only took two years before he suffered corporal punishment and public repentance at church for theft. The couple was living among the poorest parts of the population and Sophia Christina was "drinking a bit", according to the examination register. This note was changed to "drinks" a year later, indicating that her taste for alcohol had increased. The family lived at several places in the city before Sophia died, 42 years old, of a "wasting disease", probably tuberculosis.

Sophia Christina's life was of course not "representative", but it was, on the other hand, not unlike the fates of many other men and women in her surroundings. It illustrates the insecure social conditions during this transitional period. Being born, as it seems, in relatively good circumstances did not guarantee a safe and calm life. An unfortunate marriage and an ageing father, who had died when she and her mother were left alone with two young boys, became too difficult to handle within the norms and possibilities of their time. Illicit sale of alcohol was probably not the worst $\sin$ in the eyes of her neighbours, but having an illegitimate child was definitely not in accordance with the middle class perceptions of an orderly life. Alcohol became a comfort and an escape from the pains of everyday life, but probably also a cause of Sophia Christina's early death. The court's lists of fines tell 
us that this "lifestyle" was relatively common among men, but much more stigmatising when it occurred among a small minority of women.

Even those who succeeded to live within the limits of the law faced many difficulties. Brita Stina Samuelsdotter, born during the same year as Sophia Christina, was the daughter of a crofter outside Linköping. She was 12 years old, when she had to leave home and become a servant in the families of other crofters, since her biological father died and her mother re-married. She arrived in Linköping when she was 27 years old and married Petter Pettersson Mars, a former soldier (getting his last name after the Roman god of war) who had been employed as a gravedigger. Their first residence was located in a house called Fafängan (the Vanity), but the couple only stayed a while, before they continued to migrate more than once a year between the poorest houses in the city. They gave birth to three sons and one daughter, all surviving childhood. When Brita Stina was 44 years old, her husband died of a "wasting disease" at the age of 53. The widow continued to migrate within the city borders, while the children left her when they were old enough to be employed as "little servants", i.e. between 12 and 15 years of age. At the age of 55, she was left alone and entered the poorhouse, Mörnerska stiftelsen, where she spent her last 15 years in life.

The family had managed to live without poor relief while the husband was alive, but that was impossible for a lonely woman with four young children; the fate of many wives in the proletariat because of the high male mortality. But there were also more young men than women in Linköping, which meant that a lot of women became spinsters. Many of these single women had to depend on poor relief already when they were 40-50 years old, but this did not happen to Stina Larsdotter. She came to Linköping as a 25-year-old servant in the households of the upper middle class and gave birth to five children with an "unknown father". Three daughters survived childhood, living alternately with mother and foster parents. Usually housemaids stayed one or two years in the same household, and were finally pushed out of this labour market when they were 40 , but at the age of 36 , Stina became a servant in a merchant's house for 18 years. After that, she was found as an "ex housemaid" in different families or living together with widows and single mothers in situations similar to her own. Her three daughters took it in turns to live with their mother, moving away when a younger sister was old enough to assist in daily work. In the registers, mother and daughter appear like a team, sometimes 'embedded' in a wider network of social equals. This life kept Stina away from poor relief, until she died of tuberculosis, 62 years old. The youngest daughter, Emilia Augusta, stayed with her mother until the very end, and moved away from Linköping soon after the funeral.

Stina's limited luck was to become a trusted servant in the town's establishment and to have daughters, who literally stood by her side when she was old. Olof Finström's wife Brita Catharina Olofsdotter was too old for childbirth when they 
married. He came from the city of Vadstena in 1829, when he was 27 years old, and became an apprentice of a carpenter master and alderman of the guild. Olof made a career and became an independent carpenter, although not with a master's certificate. He married Brita Catharina when he was 45 and she was 44 years old. She brought an illegitimate son to the new household, who went to another town after two years.

Olof was obviously a respected member of his trade, often living in the same house as other colleagues - a sign of the social importance of occupational networks. His popularity among the clerical authorities was, however, damaged, when he asked for permission to leave the State Church and join the Evangelic Methodist Church. It took the authorities six years to grant the request, when Olof was 78 years old. At the same time, the examination registers tell us that he couple was "destitute" and remained in that situation, until they died of "old age", when Olof was 84 and Brita Catharina was 87 years old. Olof had, as far as we have reason to believe, led a decent, orderly, diligent and sober life, but that was not enough to save the family from poverty in the end. Not having children in the neighbourhood, who could help, was of course unfortunate. The register's notation about their poverty is primarily recognizing that they would not have to pay any taxes, but there is no evidence saying that they were ever receiving poor relief from the municipality. We do not know how they managed without it, but it would not be unrealistic to guess that they were assisted by their Methodist 'brothers' and 'sisters', who were expected to live up to the standards of the early Christian congregations, while at the same time symbolising the birth of new types of social networks, formed by voluntary associations.

Although each of these life histories is in one sense unique, they are all at the same time typical of how life could be in a small Swedish nineteenth-century preindustrial city. Brita Stina, like so many of her generation, came to the city in order to find work. Her family's movement from one house to another was very typical of the working class behaviour. Losing their husbands while the children were still unable to take care of themselves was a very common fate for the women and poor relief was often the only way to survive until the children could leave the home as soon as possible. Stina Larsdotter never married and, like many of the spinsters in the same generation, gave birth to several children whose fathers were said to be "unknown". Her daughters turned out to be her best 'social capital'. Among these three women, Sophia Christina illustrates the vulnerability even for those born in the lower middle class. Choosing or being forced by her pre-marital conception to marry the wrong man and losing her father when she had been left alone with two little sons was enough to change her life into misery, petty crime, drunkenness and, finally, an early death. Her case is another proof of the need for kin to rely on when life was difficult. 


\section{The Early Transition of the Agrarian Society, c. 1800-1860/70}

The transition of the classical agrarian society accelerated during the first half of the nineteenth century. Enclosure and new techniques in agriculture increased productivity. In the more densely populated rural areas, for instance in the plains in the south of Sweden, the number of farms and the workforce needed to cultivate the land were reduced. The decline of infant and child mortality after 1810 produced a rapidly growing population and a larger proportion than before became crofters, on marginal plots of land, day-labourers or had to look for work in the little pre-industrial cities. ${ }^{5}$

These cities could offer work as servants for young women and men. Traditional crafts in the cities were at the same time stagnating, which meant that the opportunities to find steady, long-lasting employment were limited. As a result, the number of owners of land stagnated and the proportion of landless increased dramatically from 1750 to 1850 in Sweden (Figure 1). The little town of Linköping and its surroundings can serve as an example of the social changes taking place. In its agrarian hinterland, about 30 percent of the men above 14 years of age had been

5 A. Brändström and L-G Tedebrand, eds., Swedish Urban Demography During Industrialisation. Report no. 10, The Demographic Data Base (Umeå University, 1995); A. Brändström and L-G Tedebrand, eds., Population Dynamics During Industrialization. Report no. 13, The Demographic Data Base (Umeå University, 2000); A. Brändström, J. Sundin and L-G Tedebrand, 'Marriage and Urban Adaption. Sundsvall and Linköping in XIXth Century Sweden', Annales de Démographie Historique, 2 (1999), 97-117; A. Brändström, J. Sundin and L-G Tedebrand, 'Two Cities. Urban Migration and Settlement in Nineteenth-Century Sweden', The History of the Family. An International Quarterly, 5:4 (2000), 415-429; I. Eriksson and J. Rogers, Rural labour and Population Change. Social and Demographic Developments in East-central Sweden During the Nineteenth Century. Studia Historica Upsaliensia 100 (Stockholm, 1978); Erland Hofsten and Hans Lundström, Swedish Population History. Main Trends from 1750 to 1970 (Stockholm, Liber, 1976); U. Jonsson, Jordmagnater, landbönder och torpare $i$ sydöstra Södermanland 1800-1880. Stockholm studies in economic history 5 ( Stockholm, 1980); Lundh, (1997); O. Lundsjö, Fattigdomen på den svenska landsbygden under 1800-talet. Stockholm studies in economic history 1 ( Stockholm, 1975); S. Martinius, Peasant destinies: the history of 552 Swedes born 1810-12. Stockholm studies in economic history 3 (Stockholm, 1977); H. Nilsson and S. Willner, Inflyttare till Linköping under 1800-talet (Centrum för Lokalhistoria, Linköpings universitet, 1994); I. Olsson, Att leva som lytt. Handikappades levnadsvillkor i 1800-talets Linköping. Linköping Studies in Arts and Science 189 (Linköping, 1999); J. Sundin and L-G Tedebrand, 'Mortality and morbidity in Swedish iron foundries 1750-1875', in Brändström and Sundin (eds.) (1981); Sundin, (1992); J. Sundin, 'Individual Change or Environmental Reform? Historical Perspectives on Responsibility and Hygienism', in Patrice Bourdelais, ed., Les Hygiènistes. Enjeux, modèles et pratiques, (Belin, 2001); J. Söderberg, Agrarian poverty in southern Sweden during the nineteenth century. Stockholm studies in economic history, 4 (Stockholm, Almqvist \& Wiksell International, 1978); J. Söderberg, U. Jonsson and Ch. Persson, A stagnating metropolis: the economy and demography of Stockholm, 1750-1850 (Cambridge, 1991); Winberg, (1977). 
Figure 1. Social structure of the agrarian population in Sweden 1751 and 1850. Number of male heads of household.

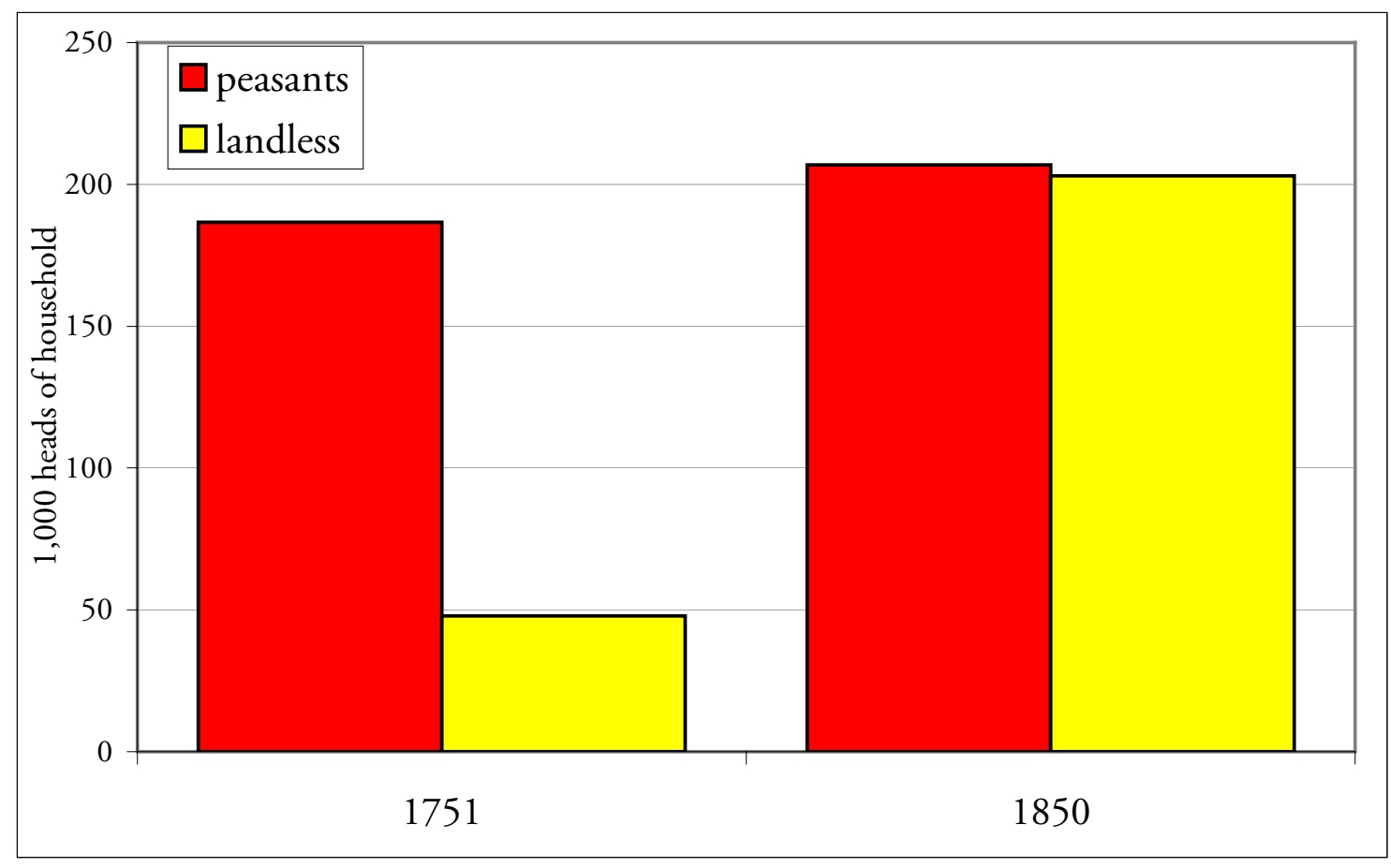

Source: C. Winberg, Folkökning och proletarisering (Göteborg 1975).

farmers in the year 1750. In addition, many young servants reached that position later in life. In 1850 this figure had been reduced to less than 20 percent. In the city itself, the percentage of male apprentices, workers and servants increased from about 50 percent in 1800 to 70 percent in 1850, while the proportion of master craftsmen and other members of the established groups decreased accordingly.

The labour market offered more jobs for female servants than for males, which created a 25 percent female surplus. Consequently, a considerable number of women could never marry. When they had reached the age of 40, most of these female servants were fired and replaced by younger candidates. Together with the widows, this group had to rely on casual work or poor relief. Similar circumstances were common among many men when they had reached what we today consider being the upper middle age. The difficulties to find steady jobs and form a family caused the average age of marriage to rise to about 30 years for both sexes among the lower classes. This, and the female surplus, contributed to a rapidly increasing illegitimacy rate. In Linköping, almost 30 percent of the children were born outside marriage during the 1820's. Another reason was the rapid population turnover. Migration was intensive and only a minority of the inhabitants had spent most of their lives in Linköping. The majority arrived as young adults and stayed for one or 
a few years. Some remained longer, but they frequently moved from one house to the other and often lacked important ties to relatives in the neighbourhood. ${ }^{6}$

Informal social control was not as tight and effective as it had been in the stable traditional society and many men could choose to deny fatherhood or refuse to marry the mother without being stigmatised by the local opinion. For some of the contemporary commentators this was seen as a general slackening of morality among the poor women. However, considering the hardships for the unmarried mother, we have no reason to believe that her situation was chosen voluntarily or wished for. Without the support of a husband, parents or other relatives, these mothers had great problems to work and take care of their newly born children at the same time. As a result, infant mortality was extremely high in this group while it remained close to the general average if the single mother could rely on the support of her closest kin.

Thus, the cities became the focus of many social problems connected with the transition that took place. For a minority these changes meant new opportunities. Besides with the traditional four stand (estates: nobility, clergy, burghers and farmers), each with specific privileges and representation in the Parliament, a new middle class emerged consisting of persons of standing and wealth outside the nobility: owners of iron foundries, successful merchants, members of the expanding civil bureaucracy and others who had managed to climb the social ladder. The social and economic gaps widened and the political influence in local affairs were to a greater extent concentrated in the hands of the elite, which created its own "Victorian" system of cultural values and felt less related to their poorer neighbours. Occasionally these social tensions manifested themselves in riots but never of a magnitude that could seriously threaten the establishment.

Everyday signs of the tensions were registered in the court's records of minor violence. ${ }^{8}$ In Linköping, as in other cities, petty fights and quarrels had been very common for centuries. Traditionally they were conflicts between social equals, starting at the pub or in other circumstances when honour was at stake and,

6 I. Artaeus, Kvinnorna som blev över. Ensamstående kvinnor under 1800-talets första hälft - fallet Västerås. Studia Historica Upsaliensia 170 (Stockholm, 1992); S. Carlsson, Fröknar, mamseller, jungfrur och pigor. Ogifta kvinnor $i$ det svenska ståndssambället. Studia Historica Upsaliensia 90 ( Stockholm, 1977); S. Carlsson, 'Kvinnoöden i Mälardalen under 1800-talet - en jämförelse mellan land och stad', Annales Academiae Regiae Scientarum Upsaliensis: 80-125 (Uppsala, 1978); Edgren, (1994); J. Sundin, 'Äktenskap, ensamskap och hälsa förr och nu. Tankar kring ett forskningsfält' in Tom Ericsson and Agneta Guillemot, eds., Individ och struktur $i$ historisk belysning. Festskrift till Sune Akerman. Forskningsrapporter från Historiska institutionen vid Umeå Universitet, 10, (Umeå, 1997).

7 M. Bengtsson, Det hotade barnet: tre generationers spädbarns- och barnadödlighet $i$ 1800talets Linköping. Linköping Studies in Art and Science, 145 (Linköping, 1996); Sundin, (1995).

8 J. Sundin, 'Theft and Penury in Sweden 1830-1920. A comparative study at the county level', Scandinavian Journal of History, 1 (1976); Sundin, (1992); Sundin, (1996 b). 
according to the tradition, had to be defended with the fists. Such events occurred even during the nineteenth century but a new type of conflict became more common than before: verbal or physical aggression against representatives of the upper classes or the guards responsible for the keeping of the peace at public places. This upsurge of social tensions was accompanied by an intensified campaign for law and order, initiated by the local elite, and the counter-resistance from those who were the targets of this control. The prosecution of drunkenness in public places is a striking example. The number of recorded cases rose year by year during the first half of the nineteenth century, to some extent reflecting an increased consumption of alcohol. It was, however, also an effect of the elite's growing sensitivity to what it considered being disorderly behaviour in the lower classes.

Other criminal offences also became more frequent during the first half of the nineteenth century. The number of thefts and other property crimes increased. Homicide rates had dropped steadily in Sweden since the end of the seventeenth century, but started to rise again after 1800 . For the major part - manslaughter alcohol was often told to be a trigger effect. While some contemporary commentators were pointing at poverty and socio-economic factors as the main cause, others were describing this new proletariat as a depraved and immoral group, a dangerous class that had to be further controlled and educated.'

\section{The Mortality Decline}

During this period, mortality trends differed depending on age and sex. For infants the figures started to decline steadily after 1810 (Figure 2 a). Usually, the greatest decline took place in areas where the mortality had been exceptionally high, i.e. in towns and certain rural areas. In places where the infant mortality rate (IMR) had been relatively low (close to 10 percent) there seemed to be a threshold preventing the figures to drop much before the end of the nineteenth century. From 1810 to 1860, however, the national figure went from 19 percent to 12 percent and in the city of Linköping it went from 37 to 16 percent. $^{10}$

9 B. Petersson, "Den farliga underklassen". Studier i fattigdom och brottslighet i 1800-talets Sverige. Umeå studies in the humanities 53 (Stockholm, 1983).

10 Bengtsson, (1996); A. Brändström, "De kärlekslösa mödrarna”. Spädbarnsdödligheten $i$ Sverige under 1800-talet med särskild hänsyn till Nedertorneå. Umeå Studies in the Humanities, 62 (Umeå, 1984); A. Brändström and L-G Tedebrand, eds., Health and Social Change. Disease, health and public care in the Sundsvall district 1750-1950. Report no. 9, The Demographic Data Base (Umeå University, 1993); A. Brändström, S. Edvinsson, and J. Rogers, 'Illegitimacy, Infant Feeding Practices and Infant Survival in Sweden 1750-1950. A Regional Analysis', Hygiea Internationalis, 3 (2002) [http://www.ep.liu.se/ej/hygiea/]; J. P. Mackenbach, 'Income inequality and population health', British Medical Journal, 324 (Jan. 2002); R. Castensson, M. Löwgren and 
Figure 2a-d. Sex- and age-specific mortality and male/female mortality ratio (females=100) in Sweden 1750-1900.
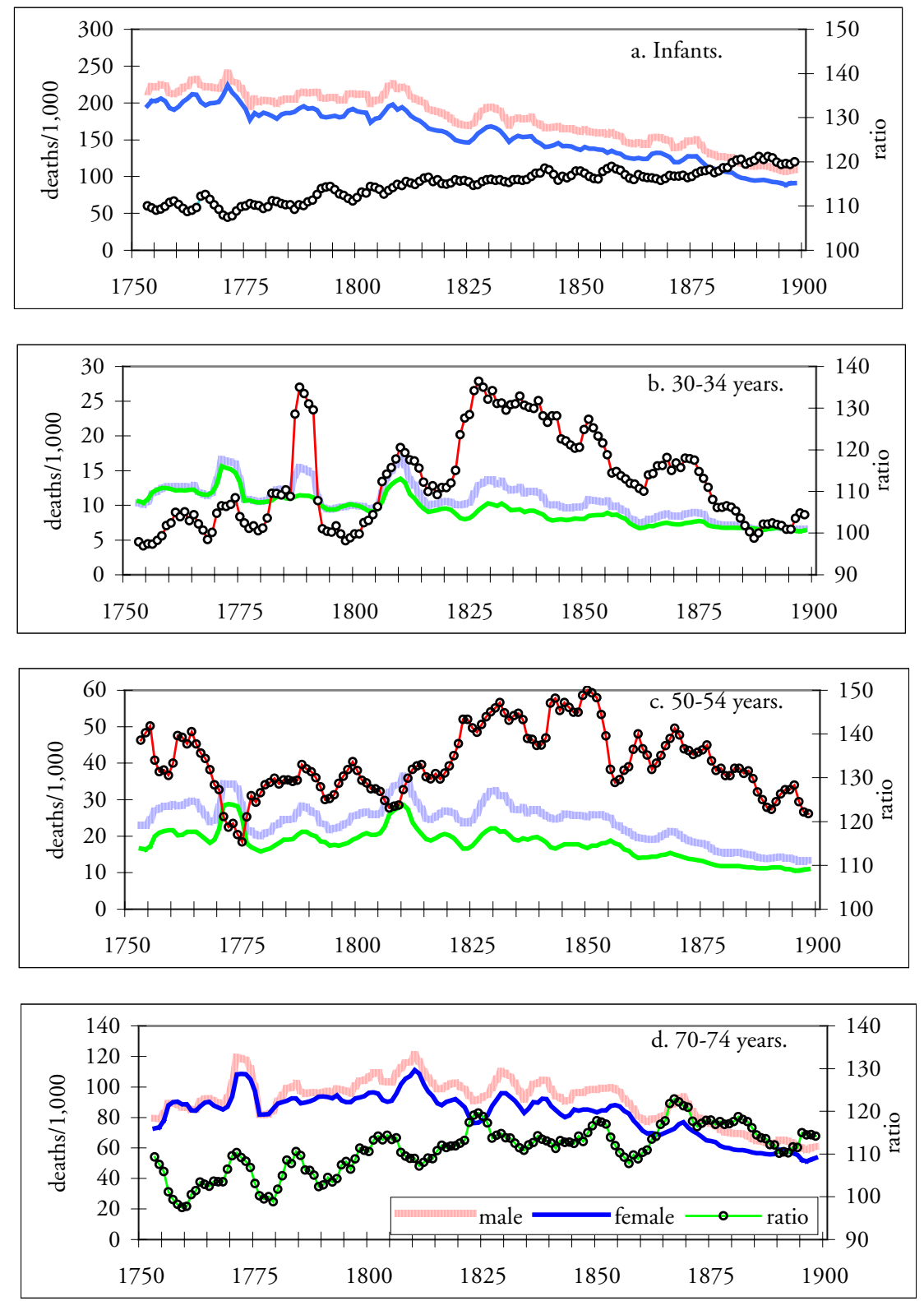

Source: G. Sundbärg, Bevölkerungsstatistik Schwedens 1750-1900 (Stockholm 1909).

J. Sundin, 'Urban Water Supply and Improvement of Health Conditions' in Anders Brändström och Lars-Göran Tedebrand, eds., Society, Health and Population During the Demographic Transition, (Stockholm, 1988); U. Högberg, Maternal mortality in Sweden. Umeå University medical dissertations, N. S. 156 (Umeå University, 1986); M. C. Nelson and J. Rogers, 'The epidemiological transition revisited. Or what happens if we look beneath the surface?', Health Transition Review, 7: 2 (1997); B-I Puranen, Tuberkulos. En sjukdoms förekomst och dess orsaker. Sverige 1750-1980. Umeå Studies in Economic History 7 (Umeå, 1984); J. Sundin, 'Environmental and other factors in health improvement explaining increased survival rates in 19th century Sweden' in Erik Nordberg and David Finer, eds., Society, environment and health in low-income countries, (Department of International Health Care Research, Karolinska institutet, Stockholm, 1990); Sundin, (1995); Sundin, (1996 a); Sundin and Tedebrand, (1981). 
Swedish authorities had access to mortality rates by sex, age and causes of death for each parish since 1749. ${ }^{11}$ They noticed the high number of incidents among infants and children and the great regional differences, a problem since a large and healthy population was supposed to be a necessary asset for the wealth of the State. ${ }^{12}$ One way to improve this situation was to invest in health care, especially by increasing the number of district physicians appointed and partly paid by the State. This was necessary in a sparsely populated country where the market for private practitioners was weak. The reform started modestly with one physician sometimes responsible for a large area where he could hardly visit each parish more than a few times during his years of service. After 1800, however, the number of positions increased steadily. A school for the training of midwives had also been established in Stockholm during the eighteenth century.

The curative and therapeutic effect of these investments may have been limited. Physicians were, however, looking upon themselves as the agents of health in a wider sense, trying to observe the patterns of disease in their districts and suggesting preventive remedies. As a well-recorded example, Carl Josua Wretholm, the physician in Nedertorneå on the northern border to Finland, noticed the high infant mortality in his district, often above 30 percent during the first decades of the nineteenth century. ${ }^{13} \mathrm{He}$ was convinced that the reason for this detrimental condition was to be found in the total lack of breast-feeding among the mothers. In the 1830's he started a campaign in order to change the habits. It was not easy to fight against a long-lasting tradition, but after he had managed to convince the farmers to hire an educated midwife, the campaign became easier. In letters to his superiors in Stockholm he could proudly report the gradual success, which had reduced the mortality figures considerably before his death in 1866 .

Nedertorneå was one of the extreme examples, but unsatisfactory breast-feeding patterns were also reported from other, if not all, parts of Sweden. Other colleagues of Wretholm's were engaged in similar campaigns. Hence, prolonged and more consistent breast-feeding, and perhaps also generally more hygienic child care, made its substantial contribution to the decline of infant mortality in a number of areas of nineteenth century Sweden.

During the second half of the eighteenth century, many Swedish physicians were engaged in attempts to inoculate against smallpox, using contagious matter from an infected person. The extent of inoculations and their effect on the overall mortality rate has been seriously questioned. At any rate, it paved the way for the very quick

11 P. Sköld, Kunskap och kontroll. Den svenska befolkningsstatistikens historia (Demografiska Databasen, Umeå Universitet, 2001).

12 K. Johannisson, Det mätbara samhället: statistik och samhällsdröm i 1700-talets Europa (Stockholm, Norstedt, 1988).

13 Brändström, (1984). 
introduction of the vaccination method demonstrated by Edward Jenner. During the first decades of the nineteenth century the big smallpox epidemics of the previous century disappeared and the mortality figures went down drastically. The success was made possible by the collaboration between national authorities, district physicians and local administration in each parish and town. The local Church was responsible for the vaccination of children, carefully recorded for each individual in the catechetical examination registers. Based upon this organisation, the campaign met relatively little resistance from the parents' side even before it became compulsory by law. For infants, but even more for children above their first year of age, the elimination of major smallpox epidemics was an important factor behind the mortality decline. Despite the social problems described above, Sweden could therefore rely on a growing number of health agents, an efficient local administration and new medical technology (vaccination) implemented within these institutional frameworks. ${ }^{14}$

Infant mortality was usually high in urban areas, even in little towns with less than 1,000 inhabitants. ${ }^{15}$ Small aggregations of people were enough to create a favourable milieu for the spread of air-, water- and food-born diseases, 'the urban penalty'. In Linköping, IMR was, for instance, often above 30 percent before 1810 . After that year, the figures went down almost uninterruptedly. Even in this case, more consistent and prolonged breast-feeding and smallpox vaccination were important factors behind the positive development. It is, however, also plausible that the campaigns for general orderliness, as recorded in the court's lists of fines, had a positive effect on people's health. From 1810 and onwards we find a growing number of convictions for neglecting to clean the gutters, spreading dirt at forbidden places, washing cloths in the river close to the place where the drinking water was fetched and other offences that worsened the hygienic conditions. In 1817 , the city magistrate decided that the place where the fresh water was taken should be moved up-streams where it could not be contaminated by the dirty surface water from the town. Limited as they were, such measures preceded more extensive attempts to clean the cities during the second half of the century, and played a role in reducing the exposure to gastro-intestinal diseases. ${ }^{16}$

In Sweden, as well as in Linköping, mortality declined after 1810 among children after their first year of life too, particularly as an effect of smallpox vaccination. When the infants faced fewer serious infections during their first year of life, they may also have become stronger and more resistant to new attacks when they grew

14 P. Sköld, The Two Faces of Smallpox. A Disease and Its Prevention in Eighteenth-and Nineteenth-Century Sweden. Report no. 12, The Demographic Data Base (Umeå University, 1996).

15 Sundin, (1995); Sundin, (1996 a).

16 Sundin, (1992). 
older. One sign of a positive synergetic effect between different diseases is seen among the infants in Linköping, where the reduction of food- and waterborne causes of death was accompanied by a similar decline of deaths by airborne diseases without any reasonable explanation why the exposure of the latter had diminished. Increased geographical mobility and population density would have created an increase of exposure, but such an effect can only be observed in the temporary rising mortality in scarlet fever and diphtheria during some decades around the middle of the century.

So far, some factors have been pointed at, which contributed to the early nineteenth century decline of infant and child mortality. Some of these factors were age specific while others, such as a general improvement of hygienic conditions, would also have been positive for adults. Positive health experiences in utero ${ }^{17}$ and in childhood have a tendency to promote good health and higher life expectancy later in life. Actually, the mortality of young and middle-aged women (Figures 2 b-c) followed the trend of the children with a visible decline after 1810. The assistance of trained midwives may also have been positive for the mothers. Maternal mortality was reduced, probably due to improved hygiene in general and especially during delivery. It declined earlier in the city of Linköping, where assisted childbirths were more common, than in the surrounding countryside where professionally trained midwives were used less frequently during the beginning of the nineteenth century. For women in the oldest ages, however, mortality did not start to decline at the same time, probably because of the materially vulnerable situation of many poor spinsters and widows. ${ }^{18}$

Summarising the mortality experience of children and women, we find that the increased survival rates are to some extent caused by conscious interventions of health agents (physicians and midwives) supported by national agencies in cooperation with local institutions. It was, in a sense, a happy meeting between Mercantilism, giving the State a reason to invest in health care institutions, and Enlightenment, believing in the possibility to discover, study, understand and influence what was previously usually seen to be God's unchangeable will. Although Sweden was a sparsely and relatively poor country, historical traditions of paternalism and local self-government based on participation and negotiation with higher authorities made these interventions successful. That does not mean that total harmony and consensus was always signifying the relations between local society and the Crown. Conflicts did occur, but compared to many other countries

17 D. J. P. Barker, Mothers, Babies and Health in Later Life (Churchill Livingstone, Edinburgh, 1998).

18 Högberg, (1986); S. Willner, Det svaga könet? Vuxendödlighet i 1800-talets Sverige. Linköping Studies in Arts and Science, 203 (Linköping, 1999). 


\section{The male puzzle}

Figure 3. Sex differences for selected causes of death, 25-49 years. Sweden 1776/80 and $1826 / 30$ ( $+=$ male surplus; $-=$ female surplus).

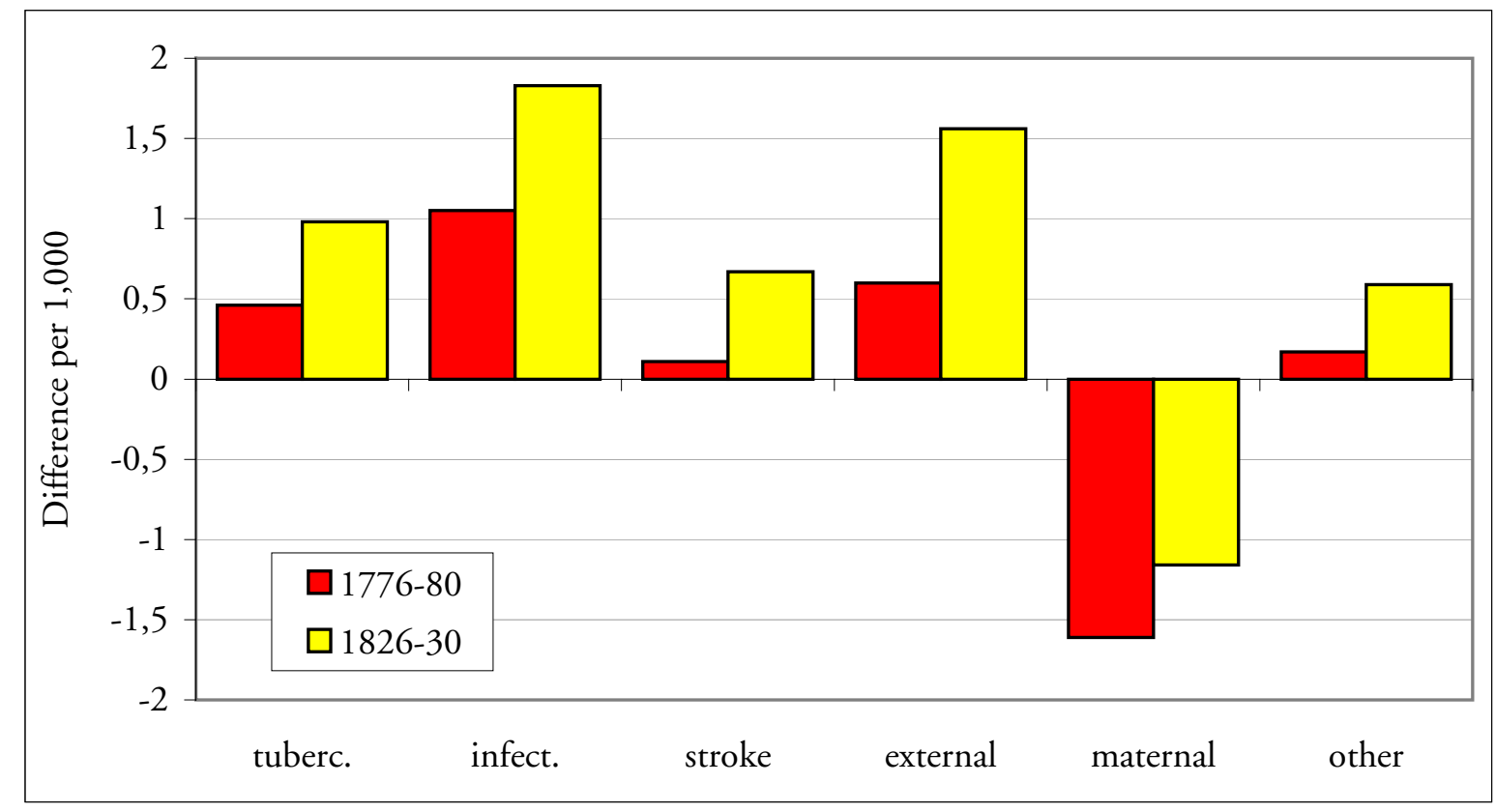

Source: S. Willner, Det svaga könet? (Linköping 1999).

at that time, Sweden was still an almost monolithic society with one State religion infiltrating the minds and institutions locally. ${ }^{19}$

For adult men, we are, however, facing an intriguing question (Figures $2 \mathrm{~b}-\mathrm{c}$ ). Why were these men not affected by the same positive factors as children and women? Or was there another negative factor, specific for men, "overshadowing" the positive effects? This negative trend for men was still strong even if we take the female reduction of maternal mortality into consideration. Hence, among the men mortality stagnated on a high level or even increased for certain age groups until the middle of the nineteenth century. ${ }^{20}$

Compared with women of the same age, the male surplus mortality existed for almost all of the contemporary registered causes of death (Figure 3). Among the most striking differences were deaths related to excessive alcohol consumption, accidents and violent deaths, suicides and tuberculosis. There was an urban/rural surplus of mortality for both sexes, but male urban mortality and the urban male/female surplus was particularly high. As has often been the case over time and

19 M. C. Nelson and J. Rogers, 'The Right to Die. Anti-vaccination Activity and the 1874 Smallpox Epidemic in Stockholm', Social History of Medicine, 5 (1992); Sköld, (1996).

20 S. Edvinsson, Den osunda staden. Sociala skillnader $i$ dödlighet i 1800-talets Sundsvall. Report no. 7 from the Demographic Data Base (Umeå, the Demographic Data Base, 1992); Söderberg et al., (1991); Willner, (1999). 
space, married persons had the lowest figures within their respective sex. Local studies in areas where the proletarianisation had started indicate that men in the lowest social strata had the highest mortality figures, while the social gradient was not visible to the same extent among women. Consequently, the highest mortality risks existed among urban unskilled male workers without a wife at their side. These variations over time, space, class and between persons with different marital status means that the male/female differences cannot be explained by simple biological factors. We must, instead, look for social and cultural determinants, i.e. gender differences.

We have no indication of early nineteenth-century Swedish men being generally materially worse off than women. The official salary for male servants was for instance twice as big as the salary for females and the labour market for women was limited to low-paid work. One difference was, however, that most unmarried women were, as housemaids, members of a household and guaranteed a minimum supply of food and shelter. Women were also, through their work roles, more accustomed to cooking, keeping a clean surrounding, etc., something that has been mentioned as a positive factor when explaining the lower mortality among unmarried women compared to unmarried men. There is also solid evidence that men in general and unmarried men in particular were allowed, or allowed themselves, to engage in more disorderly lifestyles, culturally defined negative rights.

Deaths caused by accidents have, for instance, usually been more common among men than among women, even when the accidents are not connected with a certain occupation. This difference exists already among boys at an early age, when non-gender related risks for the two sexes ought to be relatively equal. Adding the testimonies from statistics on violent deaths, deaths caused by alcohol, and the fact that men were more often involved in violent events according to the crime registers, the male role appears to be more prone to risk behaviour. Women seem to have had more 'duties' and expectations to lead an orderly, quieter life, which contributed positively to their health.

The differences by marital status were greater amongst men than amongst women. Part of these differences can probably be explained by negative selection, but it cannot explain why the differences vary in strength over time and space. Émile Durkheim's theory that marriage is an institution providing the partners with a sense of meaning and both external and self-inflicted social control, especially for men, seems to be worth taking seriously. We could therefore make a stereotype of the unmarried men as more prone to risks and unhealthy behaviour, while unmarried women, due to their internalised gender roles, were more careful and often associated themselves with more constructive networks. In Swedish preindustrial cities it has, for instance, been found that certain houses were occupied by lonely mothers and widows where they could live in some kind of symbiosis, 
elderly widows taking care of the children while the mothers were working and younger women 'paying back' with other types of help. Thus, women should have been more efficient in using their social capital. The married man was supposed to be the major breadwinner in the household, his most important and status-loaded duty. He could fulfil this responsibility as long as he had a work, giving him money to feed the family. ${ }^{21}$

So far, we have been discussing factors that could explain mortality differences between men and women and by marital status. Two key questions remain to be discussed further: Why was the male surplus mortality primarily an urban phenomenon and why was it so high during the first half of the nineteenth century? The urban penalty for males has been observed in several historical contexts, which indicates that the urban milieu may - at least under certain conditions - have characteristics that are negative for the men's health.

Secularisation came earlier to the towns and the form of social control represented by church discipline was therefore less effective. Male servants and apprentices were still often living in the households of their masters, but the masters' paternalistic influence over his employees was hard to uphold when they were off-duty and entertaining themselves. The court records tell us that female servants were not at all engaged in what was defined as unruliness and debauchery to the same extent as the males. Finding oneself in a new milieu easily lead to a sense of being uprooted. Old rules from the agrarian society did no longer work. Often lacking networks of kin and neighbours made the male immigrants more vulnerable.

Alcohol was an obvious mediator of illness and mortality (Figure 4). Although we are lacking reliable data on the consumption per capita during the first half of the $19^{\text {th }}$ century, several factors strongly indicate a substantial increase and culmination during this period, contributing to the rise in excess male mortality. Among other things, the development of the registered deaths due to alcohol intoxication culminated in the 1840s. The out-shipping of alcoholic beverages from certain production districts to other parts of Sweden increased substantially during this period. Contemporary estimates of alcohol consumption, as well as the official reports of county governors, also support this view. Alcohol could be bought at a relatively low price and the restrictions of production and sale were lenient especially in the urban areas. In towns, the number of legal pubs was large, not counting the 'speak easies', giving extra incomes to widows and other members of the poor population.

21 Sundin, (1997); J. Sundin, 'Worlds We Have Lost and Worlds We May Regain: Two Centuries of Changes in the Life Course in Sweden', The History of the Family. An International Quarterly, 4: 1 (1999). 
Figure 4. Alcohol intoxication. Registered deaths and autopsies. Sweden 18041870 .

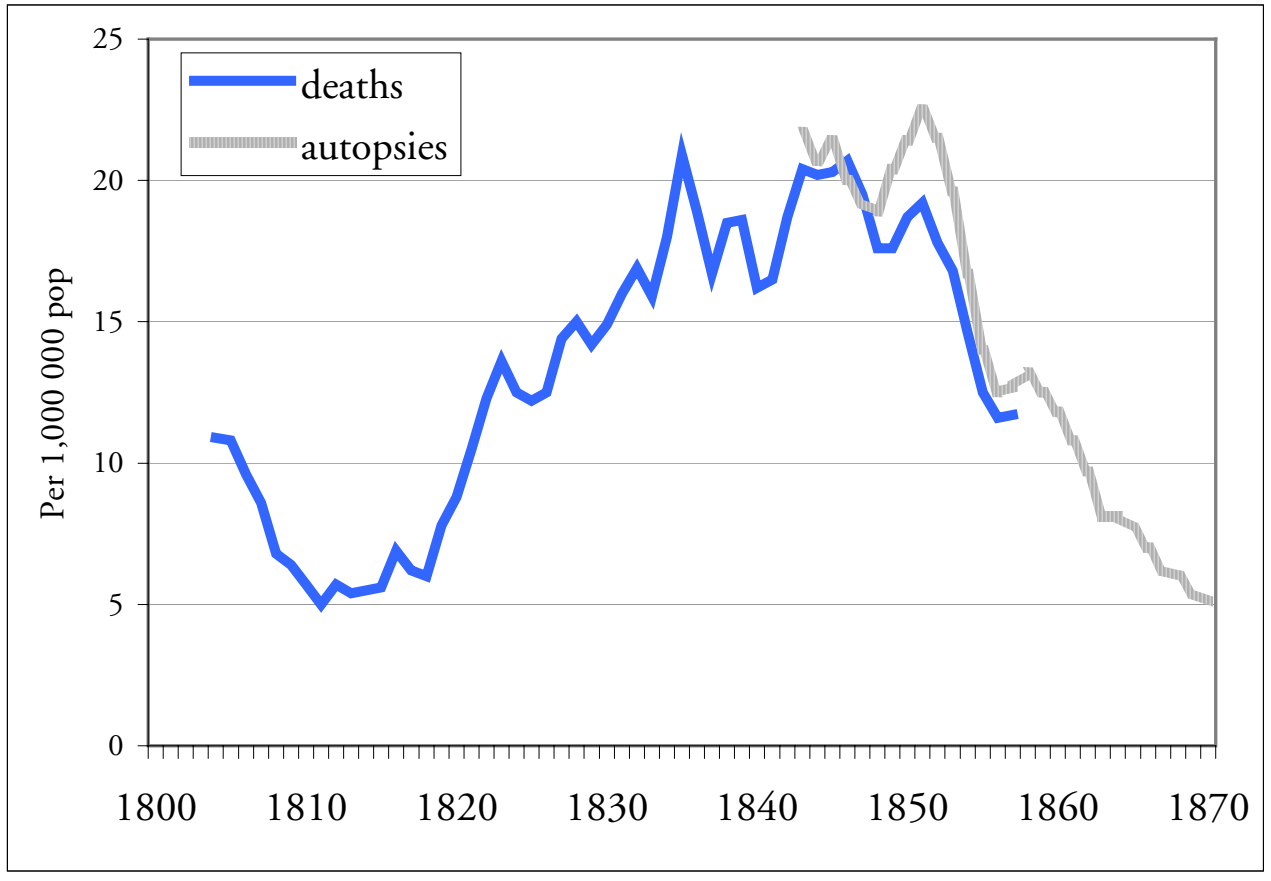

Source: S. Willner, Det svaga könet? (Linköping 1999).

Certainly, the mortality impact of alcohol consumption was much larger than the relatively few registered cases of acute alcohol intoxication. Heavy drinking affected health-related living conditions with regard to nutritional situation, housing conditions, hygiene, etc. and diagnoses such as lung consumption, stroke and external causes (primarily accidents and suicides) were to some part caused by excessive drinking.

The pioneering work, Alcoholismus Chronicus, published in two volumes 1849-51 by the Swedish physician Magnus Huss, pointed out the negative medical effects of excessive drinking, an opinion that was often seen in the medical literature as well as in the official reports of vital statistics during the second half of the century. The great socio-economic and cultural transformations of the time, which gave uncertain prospects for the future among the rapidly growing proletarian groups, contributed to a climate, which stimulated excessive alcohol consumption, as did a weakening of informal social control. For the contemporary commentators, however, the male surplus mortality was not a major topic. As we have seen, the unruly and immoral proletariat was supposed to be the dangerous 'disease'. Drunkenness in public places was primarily seen as a disturbance of the peace.

The early version of the temperance movement, in many cases initiated and led by priests, was established already before 1850. Some of them tried to form 'associations' in their parishes in which the members promised not to produce, sell 


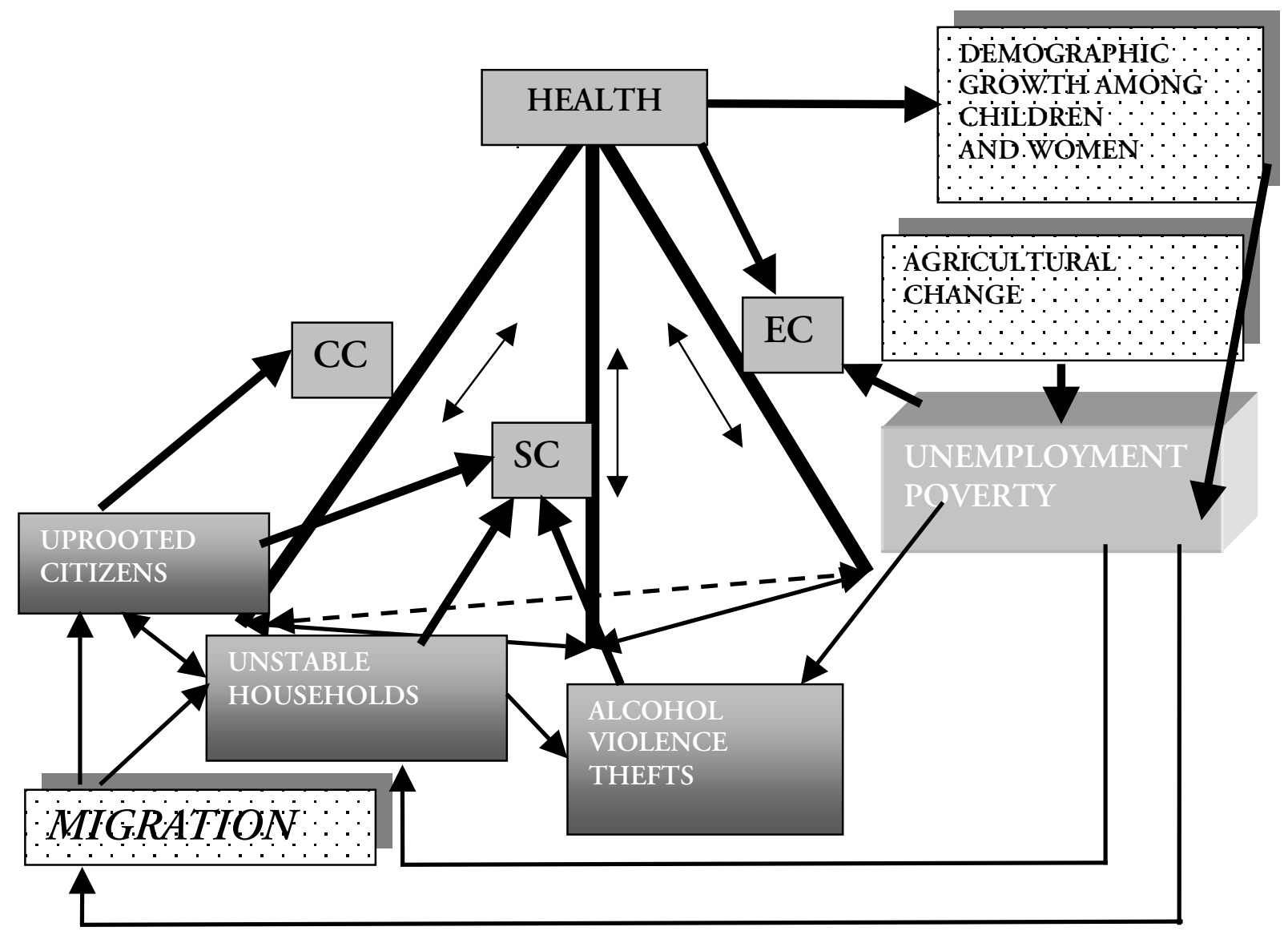

$\mathrm{CC}=$ cultural capital; $\mathrm{SC}=$ social capital $\mathrm{EC}=$ economic capital

or consume alcohol while other associations limited their ambitions to moderation. The success of these early associations is of course impossible to assess in detail, but the main impression is that it was limited. One of their weaknesses was that they were usually governed 'from above' and not spontaneously created. The society was not quite ready for real mass movements before the second half of the century. ${ }^{22}$

Figure 5 summarises some of the major factors causing the problems for the proletariat in early nineteenth century. Changes in agriculture, combined with a population growth caused by declining mortality among children and women, meant that a larger part of the population had problems to become farmers or craftsmen. The landless population grew, part of it migrating to the pre-industrial cities. The result was unemployment, poverty, unstable households, uprooted citizens and an increase of the consumption of alcohol, violence and theft. This, in

22 Sundin, (1981); Willner, (1999); S. Willner, 'The impact of alcohol consumption on excess male mortality in early 19th and 20th century Sweden', Hygiea Internationalis, 2 (2001). [http://www.ep.liu.se/ej/hygiea/.]. 
its turn, affected the economic, cultural and social resources (capital) of the same proletariat, which turned out to be most problematic for the health of middle-aged men. As we will see in the following pages, when the economy changed to the better and the society became more stable, the economic and social resources of the new working class was also improved with positive effects on the same groups that had suffered from the change in the first place. ${ }^{23}$

\section{The early phase of industrial take-off - c. $1860-1900$}

It is of course impossible to give an exact year when industrialisation started in Sweden. Already before 1860, signs of industrial activities were seen in some cities. In Norrköping, for instance, the textile industry was founded before the middle of the century. The production in traditional proto-industrial iron foundries had a peak in the 1850's and the first steam-driven sawmill in Sweden was built in 1849 . Looking for the final take-off, however, we have to move to the 1870's. Due, for instance, to wars and a general boom for the construction of ships, factories and machines and other goods in Europe and North America, the demand for wood and iron products gave Sweden favourable terms of trade on the world market. After two years of bad harvests and shortage of food by the end of the 1860 's, the labour market for industrial workers grew rapidly and real wages rose steeply. The demand for food for the workers meant that agriculture could also benefit.

The majority of the population was still engaged in agriculture, the boom did not last forever and less prosperous periods sometimes interrupted the growth. In a secular perspective, however, Sweden had definitely entered the road towards the industrial society. Stockholm, the capital, and the industrial areas, for instance the sawmill districts in the north, became places of in-migration while emigration to America was an alternative for those who did not find the future in Sweden attractive. During the first decades, the labour force was mainly recruited from the countryside and, in some of the new communities, the supply of decent housing conditions had problems to keep up with the demand. In the sawmill areas, for instance, the result was overcrowding and unmarried young men often lived in barracks where bad hygienic conditions created an inviting milieu for tuberculosis and other infectious diseases.

During the last decades of the century, pipelines for fresh water and sewerage were built in the cities and contributed to a reduction of diarrhoea and other gastrointestinal causes of death. It did, however, often take some time before the new

23 J. Sundin and S. Willner, eds., Hälsa och sambällsförändring. Olika forskarperspektiv. Institutet för framtidsstudier. Skrifter no 7 (Stockholm, 2003). 
settlements of workers could get the same facilities. Overcrowded houses and bad hygienic conditions affected everybody negatively, especially the children. Years of high demand for labour, rising real wages and an in-migration of young unmarried men resulted in an increase of the consumption of alcohol, rising numbers of arrests for drunkenness and higher mortality among adult men. The negative effects of industrialisation on life expectancy was, however, only visible in the mortality figures during a decade or two. ${ }^{24}$

Industrial production demanded that the workers should arrive sober and in time at work every day. This has been said to be a factor creating a more disciplined workforce than in the traditional crafts where time was not regulated in the same way and the employees could sometimes take a "free Monday" off. ${ }^{25}$ This new discipline also became part of the workers' own ideal, often expressed by their trade unions and political organisations. Many workers joined the temperance movement and the new "free churches", associations which, in a sense, re-established the church discipline of the agrarian society in a formally less compulsory version.

These popular movements were not only instruments for the shaping of the disciplined worker with bourgeois values of orderliness. They also provided people with new ideologies and interpretations of the world. The labour movements tried to explain the economic order and suggested how the workers should defend their rights, the temperance movement drew up the rules for a sober person and the free churches appealed to those who were religious, but rejected the hierarchical structure of the traditional State Church. Being a member in one or several of these associations was a ticket to social networks, which could help in times of hardship. Trade unions started voluntary sick insurance systems for their members and the free churches supported their members in times of unemployment or illness. The voluntary associations offered the workers a place in the new social order, which may - besides with new legal restrictions on the sales side - have contributed to the diminishing of the consumption of alcohol.

24 Brändström and Tedebrand, (1993); Edvinsson, (1992); M. C. Nelson, Bitter Bread: the famine in Norrbotten 1867-1868. Studia Historica Upsaliensia, 153 (Almqvist \& Wiksell, 1988); M. C. Nelson, 'Diphtheria in late nineteenth century Sweden: Policy and practice', Continuity and Change, 9: 2 (1994); M. C. Nelson, 'Dirt, Disease and Demography. Public Health and Infant mortality in Uppsala, 1861-1895' in Anders Brändström and L-G Tedebrand, eds., Urban Demography during Industrialization. Report No. 104 from The Demographic Data Base, (Umeå, The Demographic Data Base, 1995); Nelson and Rogers, (1992); M. C. Nelson and J. Rogers, 'Cleaning Up the Cities: The First Comprehensive Public Health Law in Sweden', Scandinavian Journal of History, 9: 2 (1994); H. Nilsson, Mot bättre hälsa. Dödlighet och hälsoarbete i Linköping 1860-1894. Linköping Studies in Arts and Science, 105 (Linköping, 1994); M. Taussi Sjöberg, Brott och straffi Västernorrland 1861-1890. Acta Universitatis Umensis, 35 (Umeå, 1981).

25 Edgren, (1987); B. Horgby, Den disciplinerade arbetaren: brottslighet och social förändring i Norrköping 1850-1910. Stockholm studies in history, 36 (Stockholm, Almqvist \& Wiksell International, 1986). 
The emergence of a new society, materially better off, socially more stable and forecasting the welfare state of the next century, offered more opportunities and less risks than early nineteenth century Sweden. Sanitary reforms in the cities contributed to the continued decline of mortality and prolonged life expectancy in all ages, the greatest relative winners being the middle-aged men. Restrictions in the production and sale of alcohol, introduced already during the 1850's, together with a self-inflicted temperance, was reflected in a reduction of the type of causes of death that were directly or indirectly linked to excessive drinking. It is also highly likely that a more stable society reduced the need to use alcohol as a "pain-killer" against social stress. These are some important causes of the improvement of the population's health, especially among the adult men, during the last decades of nineteenth-century Sweden.

\section{Summary}

Early-nineteenth-century Sweden was at the beginning of a transition of the traditional, pre-industrial agrarian society without any significant industrialization before the second half of the century. The old system for the creation of social and cultural capital was, for a growing part of the population, no longer at work. Old traditions and norms were challenged and the social mobility from one generation to the next was more often downwards than upwards. This change was particularly visible in the little pre-industrial cities, with a growing proportion of servants and unskilled workers. Young men and women migrated into the city looking for work. The majority of the towns' inhabitants were geographically and socially uprooted. Kinship networks and informal social control were looser than previously. The rapidly rising figures for illegitimate births meant that a married couple with children was no longer the only common unit of procreation. Crime rates increased for violence and thefts. The gap was widening between the elite, which could benefit from change, and the growing proletariat, in many respects the social losers.

The old institutions on the community level were, however, still at works. Educated midwives and mass vaccinations against smallpox contributed to the decline of mortality. Local medical doctors propagated for better childcare and hygienic improvement in the cities. As a consequence, mortality declined among children and adult women after 1810. Central and local authorities acted in order to strengthen the cultural and health capital of the population. No active policy was, or could, on the other hand be introduced in order to minimise the negative effects of structural economic change and the problem of the rapidly growing proletariat. The result is seen in a stagnating, and in certain age groups even increasing, male mortality. 
The positive effects of a more stable labour market were, on the other hand, demonstrated during the second half of the nineteenth century. After some decade, economic progress in the industrial society was accompanied by more stable family structures, social networks and informal associations for the working classes. These networks and associations were often established in order to take care of the interests of a specific group, but were later developed into socially wider and more diversified networks, for instance in the temperance movement or the new 'free' churches. Simultaneously, associations emerged, working on an altruistic basis in order to support vulnerable groups, for instance handicapped or single mothers. Many public officials were also engaged in voluntary associations. Public and private roles and the border between private and public action was often overlapping and diffuse. These trends precluded the negotiation between different interests during the twentieth century, which resulted in the modern welfare state. "State" then also includes the local communities, which were in fact many times taking initiatives and administrating the welfare systems. The macroeconomic development created the material basis for the strengthening and distribution of cultural, social and political resources to the majority of the population.

During the last 250 years of Swedish history, profound socio-economic changes, even if they were positive in the long run, produced winners and losers in the short run. Analysing mortality figures, the losers were sometimes found in most age groups, for instance during the 1870's and 1880's, when a deterioration of basic housing and hygienic conditions occurred in the rapidly growing industrial areas. At other occasions, adult men were the victims, due to their specific gender roles, which made them vulnerable to changes of working conditions and less stable societies. Profound changes eroded the economic, social and cultural resources for those who were less resourceful in the beginning and less able to adapt o new conditions. The restoration of welfare and health, starting during the last decades of the nineteenth century, was based on new types of the same resources, both on the individual and the collective level. An important question for today's affluent societies is whether the classical industrial époque and the old forms of the welfare state are disappearing. Is there a need for new solutions, new personal capacities and adaptations and new collective solutions for stability, safety, health and welfare for all?

Jan Sundin is Professor at the Department of Health and Society, Linköpings universitet, Linköping, SE-581 83 Linköping, Sweden. Sam Willner is Assistant Professor at the same department. 


\section{References}

Artaeus, I., Kvinnorna som blev över. Ensamstående kvinnor under 1800-talets första hälft - fallet Västerås. Studia Historica Upsaliensia 170 (Stockholm, 1992).

Barker, D. J. P., Mothers, Babies and Health in Later Life. (Churchill Livingstone, Edinburgh, 1998).

Bengtsson, M., Det hotade barnet: Tre generationers spädbarns- och barnadödlighet $i$ 1800-talets Linköping. Linköping Studies in Art and Science, 145 (Linköping, 1996).

Brändström, A., "De kärlekslösa mödrarna". Spädbarnsdödligheten i Sverige under 1800-talet med särskild hänsyn till Nedertornea. Umeå Studies in the Humanities,. 62 (Umeå, 1984).

Brändström, A. and Tedebrand, L-G. (eds.), Health and Social Change. Disease, health and public care in the Sundsvall district 1750-1950. Report no. 9. The Demographic Data Base (Umeå University, 1993).

Brändström, A. and Tedebrand, L-G. (eds.), Swedish Urban Demography During Industrialisation. Report no. 10. The Demographic Data Base (Umea University, 1995).

Brändström, A., Sundin, J. and Tedebrand, L-G., 'Marriage and Urban Adaption. Sundsvall and Linköping in XIXth Century Sweden'. Annales de Démographie Historique, 2 (1999), 97-117.

Brändström, A. and Tedebrand, L -G. (eds.), Population Dynamics During Industrialization. Report no. 13. The Demographic Data Base (Umeå University, 2000).

Brändström, A., Sundin, J. and Tedebrand, L-G.,'Two Cities. Urban Migration and Settlement in Nineteenth-Century Sweden'. The History of the Family. An International Quarterly, 5:4 (2000), 415-429.

Brändström, A., Edvinsson, S. and Rogers, J., 'Illegitimacy, Infant Feeding Practices and Infant Survival in Sweden 1750-1950. A Regional Analysis'. Hygiea Internationalis, 3 (2002). http://www.ep.liu.se/ej/hygiea/.

Carlsson, S., Fröknar, mamseller, jungfrur och pigor. Ogifta kvinnor $i$ det svenska ståndssambället. Studia Historica Upsaliensia 90 (Stockholm, 1977).

Carlsson, S., 'Kvinnoöden i Mälardalen under 1800-talet - en jämförelse mellan land och stad', Annales Academiae Regiae Scientarum Upsaliensis: 80-125 (Uppsala, 1978).

Castensson, R., Löwgren, M. and Sundin, J., 'Urban Water Supply and Improvement of Health Conditions', in Anders Brändström och Lars-Göran Tedebrand, eds., Society, Health and Population During the Demographic 
Transition, (Stockholm, Almqvist \& Wiksell International, 1988).

Edgren, L., Lärling, gesäll, mästare. Hantverk och hantverkare i Malmö 1750-1857 (Lund, Dialogos, 1987).

Edgren, M., Tradition och förändring: könsrelationer, omsorgsarbete och försörjning inom Norrköpings underklass under 1800-talet (Lund, Lund University Press, 1994).

Edvinsson, S., Den osunda staden. Sociala skillnader $i$ dödlighet $i$ 1800-talets Sundsvall. Report no. 7 from the Demographic Data Base (Umeå, The Demographic Data Base, 1992).

Eriksson, I. and Rogers, J., Rural labour and Population Change. Social and Demographic Developments in East-central Sweden During the Nineteenth Century. Studia Historica Upsaliensia 100 (Stockholm, 1978).

Harnesk, B., Legofolk: drängar, pigor och bönder i 1700- och 1800-talens Sverige. Umeå Studies in the Humanities 96 (Alqvist \& Wiksell International, 1990).

Hofsten, Erland and Lundström, Hans, Swedish Population History. Main Trends from 1750 to 1970 (Stockholm, Liber, 1976).

Horgby, B., Den disciplinerade arbetaren: brottslighet och social förändring I Norrköping 1850-1910. Stockholm studies in history, 36 (Stockholm, Almqvist \& Wiksell International, 1986).

Huss, M., Alcoholismus chronicus eller chronisk alkoholsjjukdom : ett bidrag till dyskrasiernas kännedom; enligt egen och andras erfarenhet. 1-2 ( Stockholm, 1849-51).

Högberg, U., Maternal mortality in Sweden. Umeå University medical dissertations. N. S. 156 (Umeå University, 1986).

Hörsell, A., Borgare, smeder och änkor. Ekonomi och befolkning i Eskilstuna gamla stad och Fristad 1750-1850. Studia Historica Upsaliensia 131 (Stockholm, 1983).

Johannisson, K., Det mätbara sambället: statistik och sambällsdröm i 1700-talets Europa (Stockholm, Norstedt, 1988).

Johansson, E., The History of Literacy in Sweden in comparison with some other countries (Umeå University and School of Education, Umeå, 1977).

Jonsson, U., Jordmagnater, landbönder och torpare i sydöstra Södermanland 18001880. Stockholm studies in economic history 5 (Stockholm, 1980).

Lundh, Ch., The World of Hajnal Revisited. Marriage Patterns in Sweden 16501990. Lund Papers in Economic History 60 (Lund, Department of Economic History, University of Lund, 1997).

Lundsjö, O., Fattigdomen på den svenska landsbygden under 1800-talet. Stockholm studies in economic history 1 (Stockholm, 1975).

Mackenbach, J. P., 'Income inequality and population health', British Medical Journal, 324 (Jan. 2002). 
Martinius, S., Peasant destinies: the history of 552 Swedes born 1810-12. Stockholm studies in economic history 3. (Stockholm, 1977).

Nelson, M. C., Bitter Bread: the famine in Norrbotten 1867-1868. Studia Historica Upsaliensia 153 (Almqvist \& Wiksell, 1988).

Nelson, M. C. and Rogers, J., 'The Right to Die. Anti-vaccination Activity and the 1874 Smallpox Epidemic in Stockholm', Social History of Medicine, 5 (1992).

Nelson, M. C., 'Diphtheria in late nineteenth century Sweden: Policy and practice', Continuity and Change, 9:2 (1994).

Nelson, M. C. and Rogers, J., 'Cleaning Up the Cities: The First Comprehensive Public Health Law in Sweden', Scandinavian Journal of History, 9:2 (1994).

Nelson, M. C., 'Dirt, Disease and Demography. Public Health and Infant mortality in Uppsala, 1861-1895', in Anders Brändström and L-G Tedebrand, eds., Urban Demography during Industrialization. Report No. 104 from the Demographic Data Base, (Umeå, The Demographic Data Base, 1995).

Nelson, M. C. and Rogers, J., 'The epidemiological transition revisited. Or what happens if we look beneath the surface?', Health Transition Review, 7:2 (1997).

Nilsson, H., Mot bättre hälsa. Dödlighet och hälsoarbete i Linköping 1860-1894. Linköping Studies in Arts and Science, 105 (Linköping, 1994).

Nilsson, H. and Willner, S., Inflyttare till Linköping under 1800-talet (Centrum för Lokalhistoria, Linköpings universitet, 1994).

Olsson, I., Att leva som lytt. Handikappades levnadsvillkor i 1800-talets Linköping. Linköping Studies in Arts and Science, 189 (Linköping, 1999).

Petersson, B., "Den farliga underklassen". Studier i fattigdom och brottslighet i 1800talets Sverige. Umeå studies in the humanities 53 (Stockholm, 1983).

Pleijel, H., Hustavlans värld : kyrkligt folkliv $i$ äldre tiders Sverige (Stockholm, Verbum, 1970).

Puranen, B -I., Tuberkulos. En sjukdoms förekomst och dess orsaker. Sverige 17501980. Umeå Studies in Economic History 7 (Umeå, 1984).

Sköld, P., The Two Faces of Smallpox. A Disease and Its Prevention in Eighteenth- and Nineteenth-Century Sweden. Report no. 12 from the Demographic Data Base (Umeå University, 1996).

Sköld, P., Kunskap och kontroll. Den svenska befolkningsstatistikens historia (Demografiska Databasen, Umeå Universitet, 2001).

Sundin, J., 'Theft and Penury in Sweden 1830-1920. A comparative study at the county level', Scandinavian Journal of History, 1 (1976).

Sundin, J., 'Control, punishment and reconciliation. A case study of parish justice in Sweden before 1850', in Anders Brändström and Jan Sundin, eds., Tradition and Transition. Studies in microdemography and social change. Report no. 2 from the Demographic Database, (University of Umeå, 1981).

Sundin, J. and Tedebrand, L-G., 'Mortality and morbidity in Swedish iron foundries 1750-1875', in Tradition and Transition, op. cit. (1981). 
Sundin, J., 'Environmental and other factors in health improvement explaining increased survival rates in 19th century Sweden', in Erik Nordberg and David Finer, eds., Society, environment and health in low-income countries, (Department of International Health Care Research, Karolinska institutet, Stockholm, 1990).

Sundin, J., 'Världslig pragmatism och religiöst nit. Om sexualitetens gränser i Sverige 1600-1850', Norsk Historisk Tidskrift, 2 (1991).

Sundin, J., För Gud, Staten och Folket. Brott och rättskipning i Sverige 1600-1840. Rättshistoriskt bibliotek XLVII (Lund, 1992).

Sundin, J., 'Vägen mot ett längre liv. Socialhistoriska aspekter på prevention under 1800-talet', in Ola Arvidsson and Gösta Carlsson, eds., Kampen för folkhälsan. Prevention $i$ historia och nutid, (Natur och Kultur i samarbete med FRN, Stockholm, 1994).

Sundin, J., 'Culture, Class and Infant Mortality During the Swedish Mortality Transition, c. 1750-1850’. Social Science History, 19:1 (Spring 1995).

Sundin, J., 'Child Mortality and Causes of Death in a Swedish City, 1750-1860', Historical Methods, 29:3 (1996 a), 93-106.

Sundin, J., 'For God, State and People. Crime and Local Justice in Pre-Industrial Sweden', in Eric Johnson and Eric Monkkonen, eds., The Civilization of Crime. Violence in Town and Country since the Middle Ages, (University of Illinois Press, 1996 b).

Sundin, J., 'Äktenskap, ensamskap och hälsa förr och nu. Tankar kring ett forskningsfält', in Tom Ericsson and Agneta Guillemot, eds., Individ och struktur $i$ historisk belysning. Festskrift till Sune Akerman. Forskningsrapporter från Historiska institutionen vid Umeå Universitet, 10, (Umeå, 1997).

Sundin, J., 'Worlds We Have Lost and Worlds We May Regain: Two Centuries of Changes in the Life Course in Sweden', The History of the Family. An International Quarterly, 4:1 (1999).

Sundin, J., 'Individual Change or Environmental Reform? Historical Perspectives on Responsibility and Hygienism', in Patrice Bourdelais, ed., Les Hygiènistes. Enjeux, modèles et pratiques, (Belin, 2001).

Sundin, J. and Willner, S. (eds.), Hälsa och sambällsförändring. Olika forskarperspektiv. Institutet för framtidsstudier. Skrifter no 7 (Stockholm, 2003).

Söderberg, J., Agrarian poverty in southern Sweden during the nineteenth century. Stockholm studies in economic history, 4 (Stockholm, Almqvist \& Wiksell International, 1978).

Söderberg, J., Jonsson, U. and Persson, Ch., A stagnating metropolis: the economy and demography of Stockholm, 1750-1850 (Cambridge, 1991).

Taussi Sjöberg, M., Brott och straff $i$ Västernorrland 1861-1890. Acta Universitatis Umensis 35 (Umeå, 1981). 
Willner, S., Det svaga könet? Köns och vuxendödlighet i 1800-talets Sverige. Linköping Studies in Arts and Science, 203 (Linköping, 1999).

Willner, S., 'The impact of alcohol consumption on excess male mortality in early $19^{\text {th }}$ and $20^{\text {th }}$ century Sweden', Hygiea Internationalis, 2 (2001). http://www.ep.liu.se/ej/hygiea/

Winberg, C., Folkökning och proletarisering. Kring den sociala strukturomvandlingen på Sveriges landsbygd under den agrara revolutionen. Meddelanden från Historiska Institutionen i Göteborg 10 (Göteborg, 1977). 